\title{
On the Tremadoc-Arenig and Lower-Upper Tremadoc boundries in the Bell Island Group, Conception Bay, eastern Newfoundland
}

\author{
R.K. Pickerill and D. Fillion \\ Department of Geology, University of New Brunswic, Fredericton, New Brunswick E3B 5A3
}

\begin{abstract}
The Cambro-Ordovician ichnostratigraphic paradigm developed in England and Wales and successfully applied to coeval sequences in southwest Europe and the Mediterranean region is applfed to the Ordovician Bell Island Group, Conception Bay, eastern Newfoundland. Its application enables a more accurate definition of the Tremadoc-Arenig boundary than previous studies have permitted and is the first attempt to define the Lower-Upper Tremadoc boundary within the Bell Island Group. It is 'suggested that both boundaries fall within the Beach Formation, the former at $1200 \mathrm{~m}$ within the succession and the latter at $1020 \mathrm{~m}$.

On applique au Groupe de Bell Island (Ordovicien, Baie de Conception) le modèle ichnostratigraphique développé pour le Cambro-Ordovicien d'Angleterre et du Pays de Galles et utilisé avec succès sur des séquences contemporaines d'Europe du sudouest et de la région méditerranéenne. Ceci permet de définir la frontière entre le Trémadoc et l'Arenig de façon plus exacte que lors d'études antérieures. On tente aussi de définir pour la première fols la frontè̀re sèparant le Trémadoc Inférleur du Trëmadoc supērleur à l'intérieur du Groupe de Bell Island. On suggère que les deux limites se trouvent dans la Formation de Beach, la première étant située à $1200 \mathrm{~m}$ dans la succession et la seconde à $1020 \mathrm{~m}$.
\end{abstract}

[Traduit par le journal]

\section{INTRODUCTION}

The ichnostratigraphic paradigm developed by Crimes (1970, 1975a and references therein) in fossiliferous CambroOrdovician strata of England and Wales has been successfully applied to several coeval sequences in southwest Europe and the Mediterranean region. In particular, species of Cruziana and to a lesser extent Rusophycus have been utilized to date and, or, correlate these unfossiliferous or poorly fossiliferous sequences, notable examples including Moreno et al. (1976 - central Spain), Crimes and Marcos (1976 - northwest Spain), Baldwin (1977a, 1978 - northwest Spain), Blaise and Bouyx (1980 - Brittany, Morocco) and Romano (1982 - Portuga1). In this discussion, we apply the same paradigm to a poorly fossiliferous but prolifically ichnofossiliferous sequence of ?Cambrian and Lower Ordovician (Tremadoc and Arenig) strata exposed on Bel1, Little Bell and Kellys Islands in Conception Bay, eastern Newfoundland (Fig. 1). Here the Tremadoc/Arenig age of the Orodvician strata has been wellestablished on paleontological grounds (e.g. Dean and Martin 1978) but such MARITIME SEDIMENTS AND ATLANTIC GEOLOGY $19,21-30(1983)$ studies have failed to locate the position of the TremadociArenig boundary and have not warranted comment on the position of the Lower-Upper Tremadoc boundary. In the absence of definitive faunal evidence an attempt is made herein to more closely define the position of these boundaries by adhering to previously established trace fossil stratigraphies from areas other than that under consideration (thus avoiding circular reasoning).

Such an approach can perhaps be justified when considering that the sequence, part of the Avalon Zone of Williams (1964), exhibits many similarities to several coeval southwest European and Mediterranean successions. Indeed, predrift reconstructions place the Avalon Zone of Newfoundland opposite the Moroccan coast and west of Spain during the Ordovician (Dietz and Holden 1970). Similarities can also be made on paleontological grounds, notably trilobites and graptolites (Dean and Martin 1978), particularly between the Avalon and northwestern France and the Anti-Atlas of Morocco (Dean 1976). Ranger (1978 and references therein) and more recently Hiscott (1982) have drawn attention 


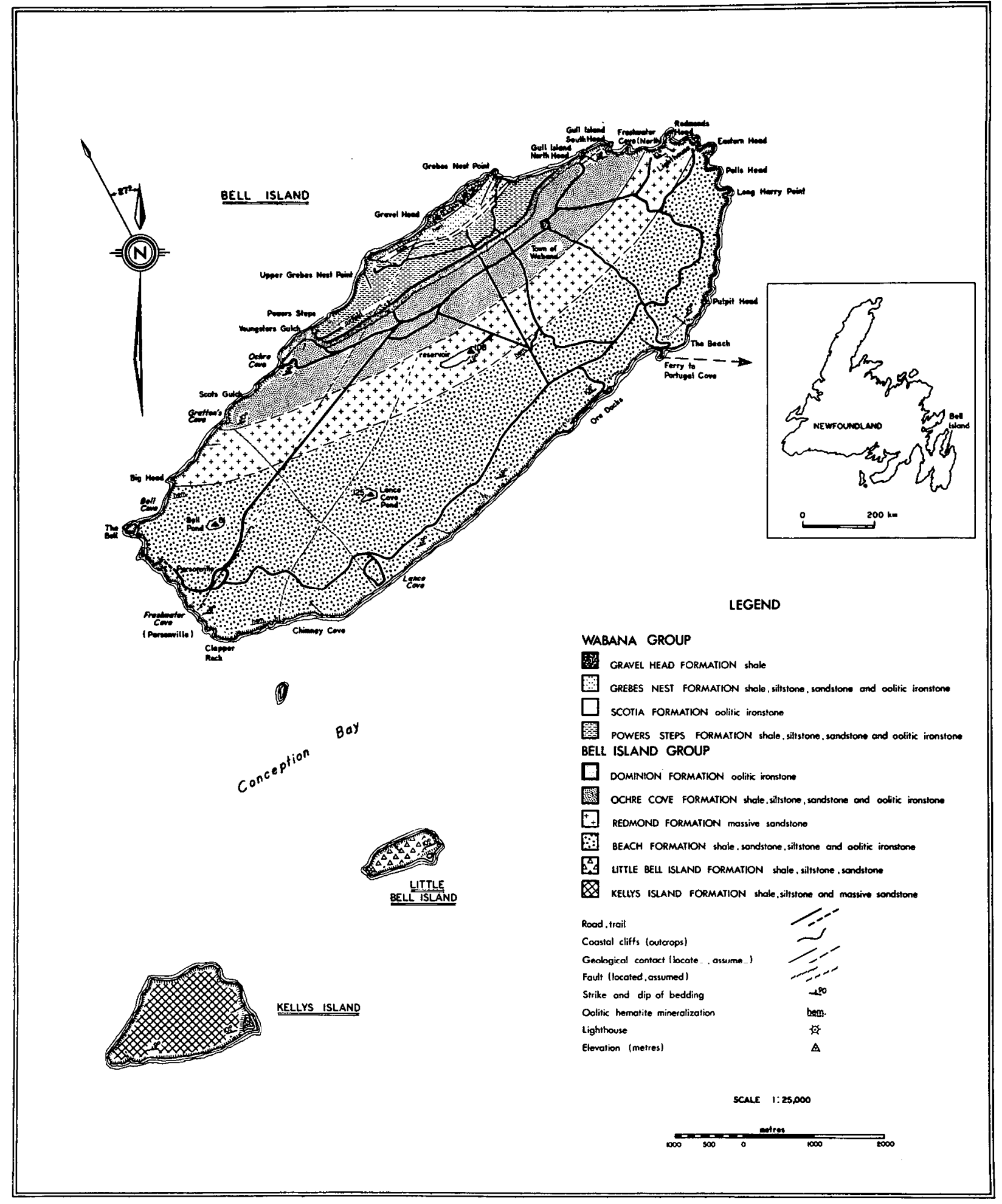

Fig. 1 - Geology of Bell Island, Little Bell Island and Kellys Island, Conception Bay, eastern Newfoundland. The geology is modified after Ranger (1978) 
to the remarkable similarity of CambroOrdovician 1ithofacies and inferred depositional environments. Finally, Seilacher and Crimes (1969), in a brief but nevertheless important review of a selection of the trace fossils from the sequence, have commented on the 'European' aspect of the Cruziana species. Pickerill and Fillion (1983) have also made additional comment on the similarity of Bell Island and European trace fossils. In view of these obvious similarities, we feel fully justified in attempting to apply the ichnostratigraphic paradigm to the sequence under consideration in an attempt to more clearly define the position of the Tremadoc-Arenig and Lower-Upper Tremadoc boundaries.

\section{LOCATION AND GENERAL STRATIGRAPHY}

Bel1 Island, Little Bell Island and
Kellys Island are located in Conception Bay, eastern Newfoundland (Fig. 1) and together are composed of a sequence of at least $1500 \mathrm{~m}$ of interbedded ?Cambrian and Ordovician (Tremadoc and Arevig) sandstones, siltstones, shales and ironstones which dip gently $\left(8-14^{\circ}\right)$ to the northwest. The sequence has traditionally been subdivided into the Bell Island Group (or Series) and an overlying Wabana Group (or Series) (van Ingen 1914, Hayes 1915, Rose 1952, Bergström 1976, Dean and Martin 1978). The most detailed formally proposed stratigraphy is that of van Ingen (1914) but alternative subdivision has been made more recently initially by Nautiyal (1966) and latterly and in more detail by Ranger (1978). Unfortunately, both of the latter schemes remain unpublished. Nevertheless, Ranger's (1978) stratigraphy has been informally adopted

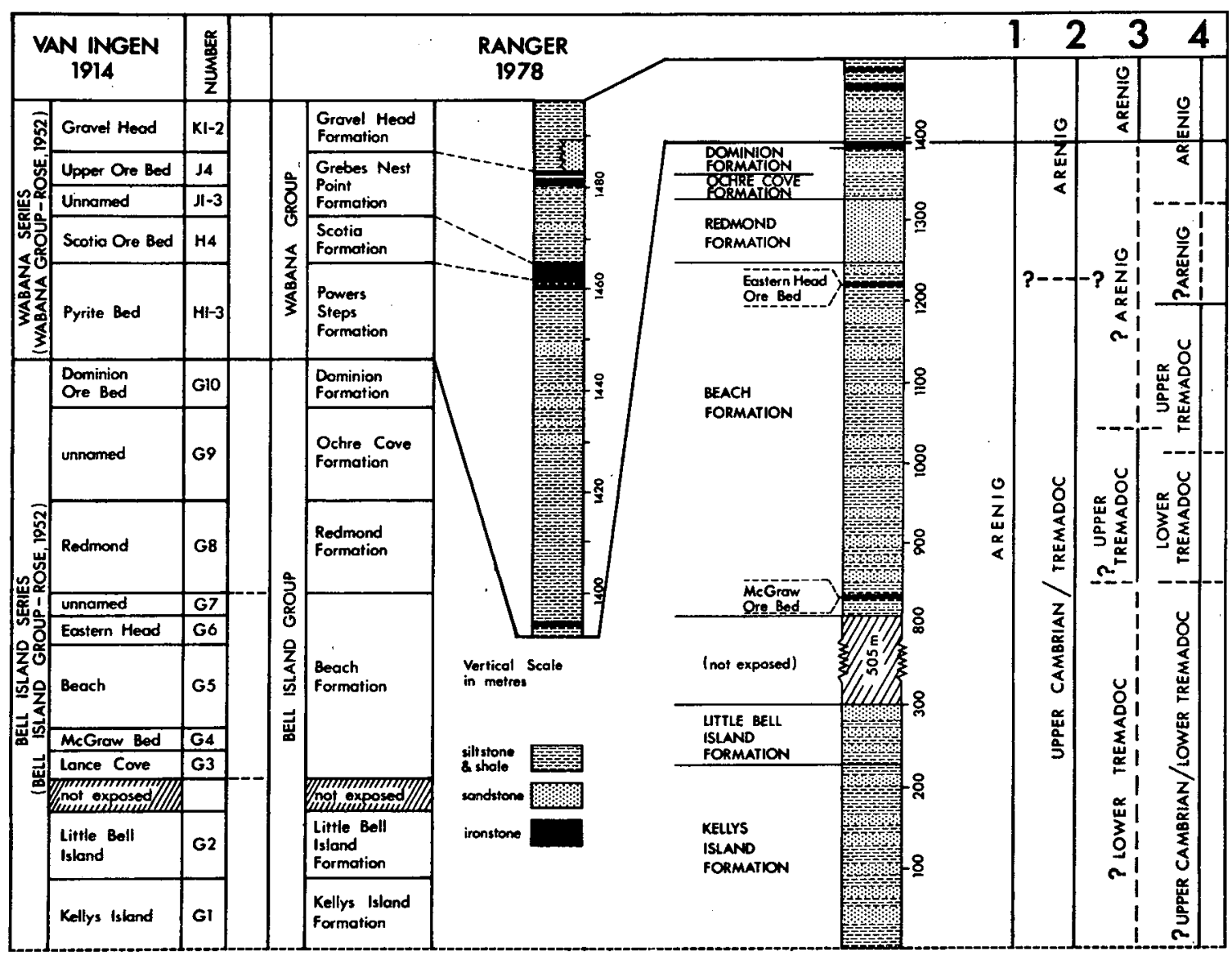

Fig. 2 - Detailed stratigraphy of the Wabana and Be1I Island Groups following van Ingen (1914) and Ranger (1978). Columns 1-4 indicate stratigraphic interpretations of the sequence: - 1 after van Ingen (1914), 2 after Bergström (1976), 3 after Dean and Martin (1978) and 4, by the present authors. 
by King (1982) and although it remains unpublished we also include it in this report, though we emphasize it should still be regarded as informal. We regard its adoption here as extremely useful for the following reasons: (i) van Ingen's (1914) scheme did not include thicknesses of individual formations/ units whereas Ranger's (1978) did. (ii) Ranger (1978) accurately located available and accessible exposures within his stratigraphic scheme. (iii) Examination of the succession over the last 2 years by us has indicated that Ranger's (1978) scheme is extremely workable. (iv) Ranger's (1978) scheme does not include unnamed units, as does van Ingen's (1914), and therefore precise reference to the succession can be made with relative ease. (v) Moreover, van Ingen's (1914) scheme does not conform to any existing code of stratigraphic nomenclature. Figure 2 summarizes both of van Ingen's (1914) and Ranger's (1978) stratigraphic schemes and for ease of comprehension of the following statements careful reference should be made to it.

There is little doubt that the Wabana Group is Lower Arenig in age, as it contains well-preserved and age diagnostic graptolites, trilobites and acritarchs (Dean and Martin 1978). Additionally, Tremadoc acritarch assemblages have been described by Dean and Martin (1978) from the Lance Cove to the lower part $(240 \mathrm{~m})$ of the Beach Formation of the Bell Island Group of van Ingen (1914). Unfortunately, fossils from the $240 \mathrm{~m}$ level of the Beach Formation upwards to the base of the Wabana Group, a stratigraphic thickness of c. $348 \mathrm{~m}$, have proved to be too imprecise with respect to either an Arenig or Tremadoc age (see Dean and Martin 1978). However, by definition the Tremadoc-Arenig boundary must lie somewhere within this succession.

The position of the Lower-Upper Tremadoc boundary within the Bell Island Group is equally epigmatic, although Dean and Martin (1978) tentatively suggested that acritarchs from the Lance
Cove Formation, McGraw Ore Bed and lower $20 \mathrm{~m}$ of the Beach Formation of van Ingen (1914) i.e. lower part of the Bell Island Group, were of Early Tremadoc age (Fig. 2), Nevertheless, the boundary is at present undefined and both macro- and microfaunal data are too imprecise to even attempt a definition of it.

NATURE AND STRATIGRAPHIC DISTRIBUTION OF TRILOBITE-PRODUCED TRACE FOSSILS

It is generally regarded by the majority of authors that Palaeozoic, particularly Lower Palaeozoic, examples of Cruziana and Rusophycus were produced by trilobites (Crimes 1970, Seilacher 1970, Hantzschel 1975). Although Seilacher (1970) united under Cruziana both long trilobite furrows and short coffeebean like excavations (=Rusophycus), subsequent authors have retained Rusophycus for the resting impressions and use Cruziana only for the furrows (see Crimes et al. 1977). This latter scheme is followed here. Additional trilobiteproduced traces have been interpreted as walking tracks (=Diplichnites), sideways grazing traces (=Dimorphichnus) and swimming grazing traces (=Monomorphichnus) (Crimes 1970). In the sequence under consideration all such traces occur in abundance, but because the ichnostratigraphic paradigm was developed employing only species of Cruziana and Rusophycus, the following section does not include detailed discussion on these latter traces although their stratigraphic distribution is, in fact, indicated in Figure 3.

Since Billings (1872) initially described a selection of the numerous species of trace fossils now known to occur within the sequence, surprisingly few and detailed studies have subsequently been undertaken. Seilacher and Crimes (1969) figured 3 specimens from Bell Island, namely, C. semiplicata, $C$. furcifera and Phycodes circinatum, and Bergström (1976) described the systematics of trilobite-produced specimens available to him. More recently Pickerill and Fillion (1983) recorded from within 


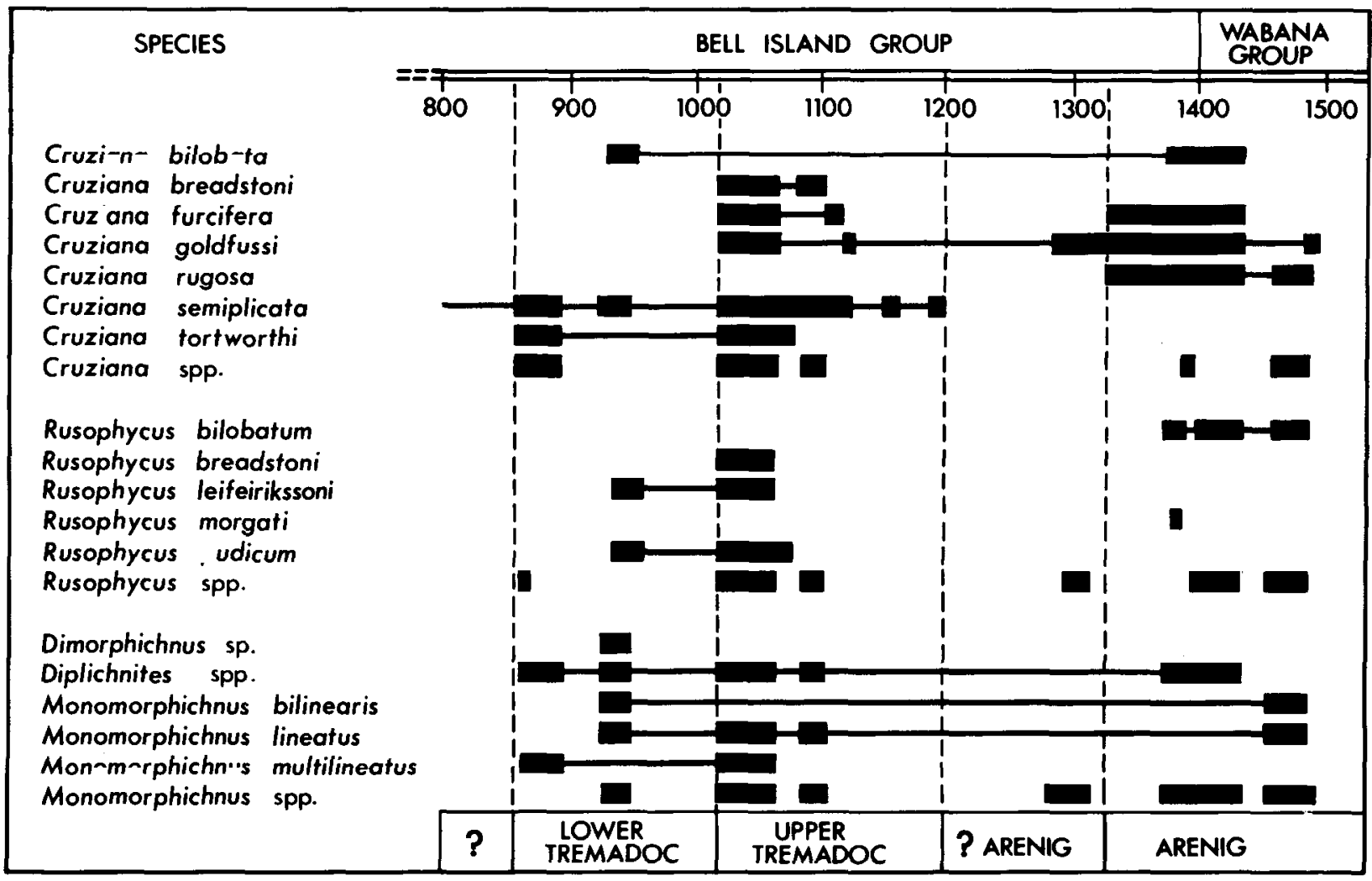

Fig. 3 - Stratigraphic distribution of trilobite-produced trace fossils within the upper part of the Bell Siland Group (800-1400 m) and the Wabana Group, and location of the Tremadoc-Arenig and Lower-Upper Tremadoc boundaries within the sequence (see text for details). The solid bars represent observed occurrences of a particular species within the sequence and the connecting lines their inferred stratigraphic distribution.

the sequences the first occurrence of Rusophycus morgati in North America and Fillion and Pickerill (1983) described the enigmatic Arthraria antiquata and its occurrence in detail. Thus, to date the most comprehensive description of the trilobite-produced species of Craziana and Rusophycus is that by Bergström (1976), but as indicated below, more detailed and systematic fieldwork undertaken by us has resulted in the discovery of additional species. A full list of all recorded trilobite-produced trace fossils and their stratigraphic distribution is indicated in Figure 3.

Species of Cruziana are represented by seven distinctive forms and several examples which, because of poor preservation, cannot be diagnosed at the specific level. In terms of van Ingen's (1914) stratigraphic scheme, the species are distributed as follows:

$$
\begin{array}{ll}
\text { Cruziana bilobata } & \text { - Units G5, G9, } \\
& \text { H2 } \\
\text { Cruziana breadstoni } & \text { - Unit G5 } \\
\text { Cruziana furcifera } & \text { - Top of Unit G5 - } \\
& \text { J4 } \\
\text { Cruziana goldfussi } & \text { - Units G5, G8 - } \\
& \text { G10, H1-H3 } \\
\text { Cruziana rugosa } & \text { - Units G9-J4 } \\
\text { Cruziana semiplicata - Units G1-G5 } \\
\text { Cruziana tortworthi - Units G3-G5 }
\end{array}
$$

Species of Rusophycus are represented by five distinctive forms which, in the same stratigraphic scheme, are distributed as follows:

$$
\begin{array}{lc}
\text { Rusophycus bilobatum } & \text { - Units G9 - } \\
& \text { J4 } \\
\text { Rusophycus breadstoni } & \text { - Unit G5 } \\
\text { Rusophycus leifeirikssoni } & \text { - Unit G5 } \\
\text { Rusophycus morgati } & \text { - Top of } \\
& \text { Unit G9 } \\
\text { Rusophycus pudicum } & \text { - Unit G5 }
\end{array}
$$



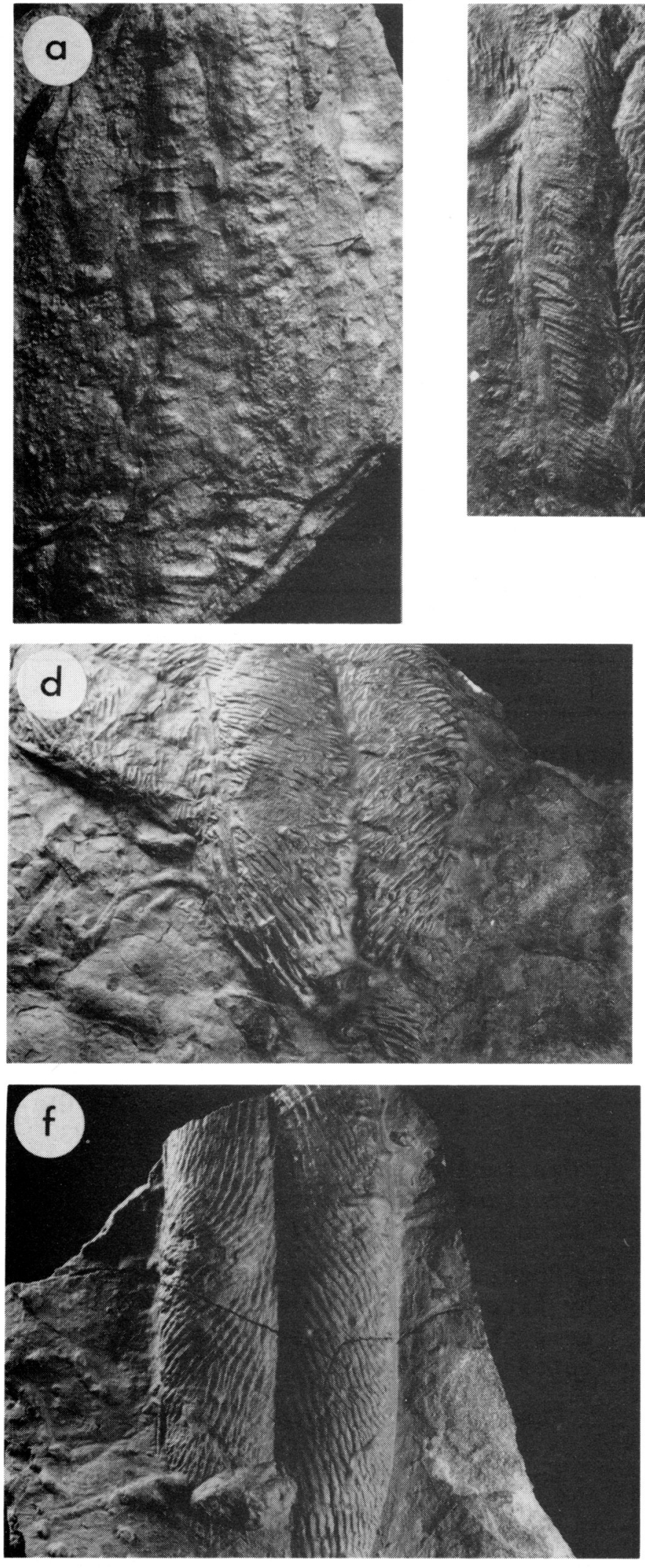
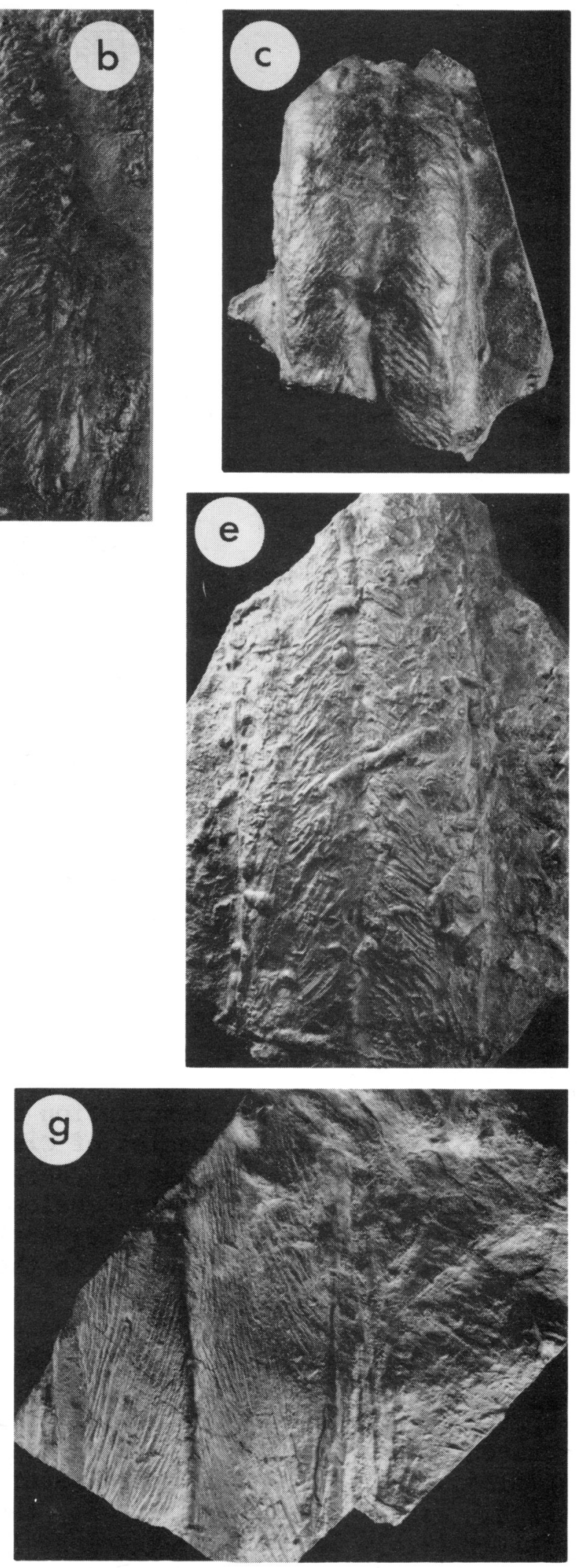
of these species, $C$. rugosa, $C$. furcifera, $C$. semiplicata, $R$. leifeirikssoni and $R$. pudicum have been described in detail by Bergström (1976). The remaining species, together with the non-trilobite produced trace fossils, will be described in a forthcoming monograph by the present authors (Fillion and Pickerill, in preparation).

\section{DISCUSSION}

The following discussion places more emphasis on species of Cruziana. Species of Rusophycus are not as stratigraphically useful because to date few and detailed systematic studies have been undertaken. Wherever applicable, however, brief reference is made to relevant rusophycids. All species of Cruziana are illustrated in Figure 4.

\section{Tremadoc-Arenig boundary}

Seilacher and Crimes (1969) were the first to suggest that, based on the occurrence of both $C$. semiplicata and $C$. furcifera, the Cambrian-Ordovician boundary (but unfortunately without reference to the Tremadoc) would fall within the sequence on Bell Island. Bergström (1976) restudied a selection of the trace fossils and tentatively placed the Tremadoc-Arenig boundary at the base of the Eastern Head - G6 Unit of van Ingen (1914) $(=$ the Eastern Head Ore Bed of Ranger (1978), stating that the trilobite-produced traces occurring above this were of "C. furcifera type" and $C$. semiplicata was absent. In spite of the fact that both on Bell Island and elsewhere $C$. furcifera occurs in both Tremadoc and Arenig strata Bergström's questionable boundary does not differ significantly from that suggested herein. Detailed paleontological studies by Dean and Martin (1978) failed to accurately locate the Tremadoc-Arenig boundary but did suggest its presence between the $240 \mathrm{~m}$ level of the Beach Formation and the base of the Wabana Group (see general stratigraphy section). This sequence of $c .348 \mathrm{~m}$ was tentatively assigned an Arenig age based on the stronger Arenigian affinities of the acritarch faunas.

In the Welsh, southwest European and Mediterranean ichnofossiliferous sequences, the Tremadoc-Arenig boundary is defined on the presence or absence of $C$. semiplicata and $C$. rugosa (Crimes 1970, 1975a; Baldwin 1977a, 1978). C. semiplicata is distinctly Upper CambrianTremadocian (Crimes 1970, Seilacher 1970) and the base of the Arenig is placed after its last occurrence within a particular sequence (e.g. Baldwin 1978). Additionally, C. rugosa is a distinctive Arenig-Llandeilo form and does not range into the Tremadoc (Crimes 1975a, Baldwin 1977a). C. tortworthi is only known from Tremadoc age strata (Crimes 1975b) but unfortunately, until now, from only a single locality in Gloucestershire, England. Its usefulness as a stratigraphic indicator is unresolved although it is noteworthy that its occurrence in the Bell Island Group is within strata interpreted by the present authors and Dean and Martin (1978) as Tremadoc in age. All the additionally listed species of Cruziana are of little value in the definition of the Tremadoc-Arenig boundary as both on Bell Island and elsewhere they are long-ranging forms.

In the Bell Island Group, the last recorded occurrence of $C$. semiplicata is at $1200 \mathrm{~m}$ within the succession, that is, the upper part of the Beach - G5 of van Ingen (1914) or the Beach Formation of Ranger (1978) (Fig. 2). Application

Fig. 4 - Species of Cruziana from the Bell Island and Wabana Groups, Conception Bay, eastern Newfoundland. a) C. bilobata; location Ore Docks (Unit G5), x 1.0. b) C. tortworthi; location Lance Cove (Unit G3), x0.8. c) C. breadstoni; location The Beach (Unit G5), $x 0.7$. d) $C$. rugosa; location Upper Grebes Nest Point (Unit J4), x 0.5. f) C. furcifera; location Ochre Cove (Unit G9), x 0.6 . g) $C$. goldfussi; location Gull Island North Head (Unit G 10), x 0.5. A11 specimens from the Bell Island Group with the exception of $d$ from the Wabana Group. Individual locations given in Figure 1. 
of the ichnostratigraphic paradigm necessitates placing the Tremadoc-Arenig boundary at this level. Note that $C$. tortworthi occurs below this level in strata assigned a Tremadoc age. The first occurrence of $C$. rugosa is at $1330 \mathrm{~m}$, that is, at the base of unnamed Unit-G9 of van Ingen (1914) or the Ochre Cove Formation of Ranger (1978) (Fig. 2). All strata above this level are therefore regarded as Arenig in age. It is also noteworthy that at $1355 \mathrm{~m}$ also occurs Rusophycus morgati, a distinctive Arenig rusophycid (Baldwin 1977b). Unfortunately, between 1200$1330 \mathrm{~m}$ only $c$. goldfussi has been recorded, which is a wide ranging species. The absence of $C$. semiplicata and $C$. rugosa from this level may well be related to facies control, as this part of the sequence consists essentially of thick cross-bedded and megarippled orthoquartzites which have a low preservation potential for trilobite-produced trace fossils. Thus, the Tremadoc-Arenig boundary may well lie within this sequence. Because this is impossible to resolve with existing data, we place the Tremadoc-Arenig boundary at $1200 \mathrm{~m}$ and questionably refer to the $1200-1300$ $\mathrm{m}$ section as ?Arenigian in age.

\section{Lower-Upper Tremadoc boundary}

To date there has been no attempt to locate the position of the Lower-Upper Tremadoc boundary within the sequence although Dean and Martin (1978) did note that a single acritarch species (Arbusculidium destombesii) from the Lance Cove Formation, McGraw Ore Bed and lower $20 \mathrm{~m}$ of the Beach Formation of van Ingen (1914) suggested an early Tremadoc age (Fig. 2). The ichnostratigraphic paradigm suggests the boundary is located at $1020 \mathrm{~m}$, that is, within the Beach G5 Unit of van Ingen (1914) and Beach Formation of Ranger (1978) (Figs. 2,3). In the Cabos Series of northwestern Spain, $c$. furcifera and $c$. goldfussi do not occur in Lower Tremadoc strata (Baldwin 1977a). Similarly, in England and Wales $C$. furcifera is essentially restricted to Upper Tremadoc and younger strata (Crimes 1970). The first occur- rence of these species in the Bell Island Group is entirely coincident at the 1020 m level, where we therefore place the Lower-Upper Tremadoc boundary. It is noteworthy that if this boundary is accepted, the stratigraphic range of both $c$. tortworthi and $C$. breadstoni is now extended into strata of Upper Tremadoc age. The former species has previously only been recorded from Lower Tremadoc strata of Gloucestershire, England (Crimes 1975) and the latter from the same sequence and the Lower Tremadoc of northwest Spain (Crimes and Marcos 1976). Nevertheless, their distribution within the Bell Island Group suggests they may well be definitive Tremadocian species. In addition, therefore, their first appearance at $855 \mathrm{~m}$ suggests that strata between this level and $1200 \mathrm{~m}$ are definitively Tremadoc in age. Strata below $855 \mathrm{~m}$ could conceivably be of Upper Cambrian or Lower Tremadoc age, as they contain no diagnostic trace fossils (Fig. 2).

\section{SUMMARY}

The ichnostratigraphic paradigm developed by Crimes $(1970,1975 a)$ in Eng1 and and Wales has been successfully applied to coeval sequences in southwest Europe and the Mediterranean region. Its application to the ?Cambro-Ordovician strata (Be11 Island and Wabana Groups) of eastern Newfound 1 and has resulted in a more accurate but not totally precise definition of the TremadocArenig boundary. It is suggested this boundary be placed at $1200 \mathrm{~m}$ within the succession, that is in the upper part of the Beach - G5 Unit of van Ingen (1914) or the Beach Formation of Ranger (1978) within the Bell Island Group. Above this level are $130 \mathrm{~m}$ of questionable Arenig strata followed by a further 170 $m$ of definitive Arenig strata. It is further suggested that the Lower-Upper Tremadoc boundary be placed at $1020 \mathrm{~m}$ within the succession, that is $180 \mathrm{~m}$ below the Tremadoc-Arenig boundary and also within the Beach Formation.

\section{ACKNOWLEDGEMENTS}

We wish to thank Drs. T. Harland, G. 
Plint and A. King for reviewing the initial manuscript and Dr. T.P. Crimes for examining a selection of the trace fossils described herein. The research was supported by Natural Sciences and Engineering Research Council of Canada Grant A3857 to R.K. Pickerill, which is gratefully acknowledged. Technical assistance was provided by $\mathrm{R}$. McCulloch, S. Aitken and J. Ley.

BALDWIN, C.T. 1977a. The stratigraphy and facies associations of trace fossils in some Cambrian and Ordovician rocks of north western spain. In Trace fossils 2, Edited by T.P. Crimes and J.C. Harper. Geological Journal Special Issue Number 9, Seel House Press, Liverpool.

1977b. Rusophycus morgati

and asaphid produced trace fossil from the Cambro-Ordovician of Brittany and northwest Spain. Journal of Paleontology, 51, pp. 411-425.

1978. A comparison of the stratigraphy and depositional processes in the Cambro-Ordovician rocks of the Cantabrian and West Asturian-Leonese Zones, N.W. Spain. Breviora Geologica Asturica (Institute de Estudios Asturianos), Special Publication 27, pp. 44-70.

BERGSTRÖM, J. 1976. Lower Palaeozoic trace fossils from eastern Newfoundland. Canadian Journal of Earth Sciences, 13, pp. 1613-1633.

BILLINGS, E. 1872. On some fossils from the primordial rocks of Newfoundland. Canadian Naturalist, New Series 6, pp. 465-479.

BLAISE, J. and BOUYX, E. 1980. Les séries cambro-ordoviciennes à Cruziana et le problème de l'extension septentrionale des plates-formes "périgondwaniennes" durant le Paléozoique inférieur. Acadèmie des Sciences, Compte Rendus Hebdomadaires des Séances, Série D, Sciences Naturelles, Paris, 291, pp. 793-796.

CRIMES, T.P. 1970. The significance of trace fossils in sedimentology, stratigraphy and palaeoecology with examples from Lower Palaeozoic strata. In Trace fossils. Edited by T.P. Erimes and"J.C. Harper. Geological Journal Special Issue Number 3, Seel House Press, Liverpool, pp. 101-126.

1975a. The stratigraphical significance of trace fossils. In The Study of Trace Fossils. Edited by R.W. Frey. Springer-Verlag, Berlin-New York, pp. 109-130.

1975b. Trilobite traces from the Lower Tremadoc of Tortworth. Geological Magazine, 112, pp. 33-46.

CRIMES, T.P. and MARCOS, A. 1976. Trilobite traces and the age of the lowest part of the Ordovician reference section for NW Spain. Geological Magazone, 113, pp. 349-356.

CRIMES, T.P., LEGG, I., MARCOS, A. and ARBOLEYA, M. 1977. ?Late Precambrianlow Lower Cambrian trace fossils from Spain. In Trace fossils 2. Edited by T.P. Crimes and J.C. Harper. Geological Journal Special Issue Number 9, Seel House Press, Liverpool, pp. 91138.

DEAN, W.T. 1976. Some aspects of Ordovician correlation and trilobite distribution in the Canadian Appalachians. In The Ordovician System. Edited by M.G. Bassett. University of Wales Press and the National Museum of Wales, Cardiff, pp. 227-250.

DEAN, W.T. and MARTIN, F. 1978. Lower Ordovician acritarchs and trilobites from Bell Island, eastern Newfoundland, Geological Survey of Canada Bulletin 284, 35p.

DIETZ, R.S. and HOLDEN, J.C. 1970. The breakup of Pangea. Scientific American, 223, pp. 30-41.

FILLION, D. and PICKERILL, R.K. 1983. On Arthraria antiquata Billings, 1872 and its relationship to Diplocraterion Torell, 1870 and Bifungites Desio, 1940. Journal of Paleontology, 57, (in press). 
aration). Trace fossils from the ?Cambro-Ordovician Bell Island and Wabana Groups, northeastern Newfoundland.

HÄNTZSCHEL, W. 1975. Trace fossils and problematica. In Treatise on invertebrate paleontology, Part W, Misce1lanea. Edited by C. Teichert. University of Kansas Press and Geological Society of America. Lawrence, KS, pp. W1-W296.

HAYES, A.0. 1915. Wabana Iron Ore of Newfoundland. Geological Survey of Canada Memoir 7.8, 163p.

HISCOTT, R.N. 1982. Tidal deposits of the Lower Cambrian Random Formation, eastern Newfoundland: facies and paleoenvironments. Canadian Journal of Earth Sciences, 19, pp. 2028-2042.

KING, A.F. 1982. (Compiler). The Caledonide Orogen. Guidebook for Avalon and Meguma Zones, IGCP Project 37, NATO Advanced Study Institute, Report $9,308 \mathrm{p}$.

MORENO, F., VEGAS, R. and MARCOS, A. 1976. Sobre la edad de las serias Ordovícicas y Càmbricas relacionadas con 1a discordancia "sàrdica" en el anticlinal de Valdelacasa (Montes de Toledo España). Breviora Geologica Astùrica, 20, pp. 8-16.

NAUTIYAL, A.C. 1966. The Cambro-Ordovician Sequence in the Southeastern Part of the Conception Bay Area, Eastern Newfoundland. Unpublished M.Sc. thesis, Memorial University of Newfoundland, 334p.

PICKERILL, R.K. and FILLION, D. 1983. Occurrence of Rusophycus morgati in Arenig strata of Bell. Island, eastern Newfoundland. Journal of Paleontology, 57 (in press).
RANGER, M.J. 1978. The stratigraphy and depositional environment of the Bell Island Group, the Wabana Group, and the Wabana Iron Ores, Conception Bay, Newfoundland. Unpublished M.Sc. thesis, Memorial University of Newfoundland, 216p.

ROMANO, M. 1982. The Ordovician biostratigraphy of Portugal - A review with new data and re-appraisal. Geological Journal, 17, pp. 89-110.

ROSE, E.R. 1952. Torbay map-area, Newfoundland. Geological Survey of Canada Memoir 265, 64p.

SEILACHER, A. 1970. Crużiana stratigraphy of "non-fossiliferous" Palaeozoic sandstones. In Trace fossils. Edited by T.P. Crimes and J.C. Harper. Geological Journal Special Issue Number 3, Seel House Press, Liverpool, pp. 447-476.

SEILACHER, A. and CRIMES, T.P. 1969. "European" species of trilobite burrows in Eastern Newfoundland. In North Atlantic - geology and continental drift, a symposium. Edited by M. Kay. American Association of Petroleum Geologists Memoir 12, pp. 145-148.

VAN INGEN, G. 1914. Table of the geological formations of the Cambrian and Ordovician systems about Conception and Trinity Bays, Newfoundland, and their north-eastern American and western European equivalents, based upon the 1912-1913 fieldwork. Princeton University Contributions to the Geology of Newfoundland, Number 4, 1p.

WILLIAMS, H. 1964. The Appalachians in northeastern Newfoundland - a twosided symmetrical system. American Journal of Science, 262, pp. 1137-1158. 